\title{
Study on the mechanical properties of BFRP tube confined concrete short columns under axial compression
}

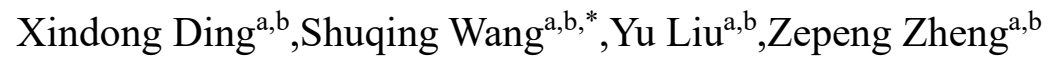

${ }^{\mathrm{a} C o l l e g e ~ o f ~ E n g i n e e r i n g, ~ O c e a n ~ U n i v e r s i t y ~ o f ~ C h i n a, Q i n g d a o, 266100, C h i n a ~}$

${ }^{b}$ Key Laboratory of Ocean Engineering of Shandong Province, Ocean University of China,Qingdao,266100,China

\begin{abstract}
Axial compression tests were carried out on 6 square steel tube confined concrete short columns and 6 BFRP square pipe confined concrete axial compression tests. The concrete strength grades were $\mathrm{C} 30, \mathrm{C} 40$, and $\mathrm{C} 50$. The test results show that the failure modes of steel pipe and BFRP pipe are obviously different, and the BFRP pipe undergoes brittle failure. Compared with the short columns of concrete confined by BFRP pipes, the ultimate bearing capacity of axial compression is increased by $-76.46 \%,-76.01 \%$, and $-73.06 \%$, and the ultimate displacements are $-79.20 \%$, $-80.78 \%,-71.71 \%$.
\end{abstract}

Key Words:BFRP square tube;Concrete short column;Axial compression test;Simulation analysis

\section{Introduction}

The BFRP square tube confined concrete column is a composite member composed of BFRP square tube and concrete. The schematic cross section is shown in Figure 0-1. 


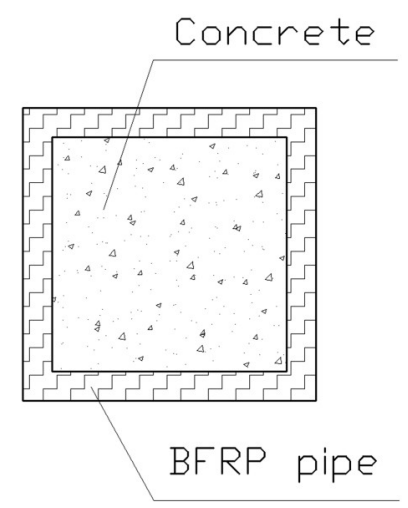

Figure 0-1 Schematic diagram of cross section of BFRP pipe restrained concrete member

Fiber reinforced composite material (Fiber Reinforce Plastic) is a high-strength artificial composite material with superior performance. According to different types of fiber materials, common basalt fiber reinforced composite materials (abbreviated as BFRP) and carbon fiber reinforced composite materials (abbreviated as CFRP), Glass fiber reinforced composite materials (abbreviated as GFRP) and aramid fiber reinforced composite materials (abbreviated as AFRP). According to the shape of the composite material, the common FRP forms are sheet (cloth and plate), rod (rib and rope), profile (tubular and solid), etc. The performance indexes of several common fiber composite materials are shown in Table $0-1$.

Table 0-1 Several common physical performance indexes of fiber reinforced composite materials

\begin{tabular}{cccccc}
\hline Type & $\begin{array}{c}\text { Tensile } \\
\text { Strength } \\
M P a\end{array}$ & $\begin{array}{c}\text { Elastic } \\
\text { Modulus } \\
G P a\end{array}$ & $\begin{array}{c}\text { Maximum } \\
\text { elongation } \\
\%\end{array}$ & $\begin{array}{c}\text { Fiber } \\
\text { density } \\
\mathrm{g.cm}^{-3}\end{array}$ & $\begin{array}{c}\text { Operating } \\
\text { temperature } \\
\text { range }\end{array}$ \\
\hline BFRP & $3000 \sim 4800$ & $80 \sim 110$ & 3.3 & 2.65 & $-200 \sim 650$ \\
CFRP & $3500 \sim 6000$ & $230 \sim 600$ & 5.2 & 1.74 & 500 \\
GFRP & $3100 \sim 4650$ & $73 \sim 86$ & 2.2 & 2.49 & $-60 \sim 350$ \\
AFRP & $2900 \sim 3400$ & $70 \sim 140$ & 3.6 & 1.47 & 250 \\
\hline
\end{tabular}

Dong Lei ${ }^{[1]}$ conducted an axial compression test on reinforced concrete columns 
confined with FRP cloth. He changed the type of fiber cloth material, the number of layers of fiber cloth winding, the spacing of fiber cloth, the strength grade of concrete, and the size of the column to study the columns. The axial pressure performance. The research results show that the effect of restraining the lateral deformation of reinforced concrete columns confined by FRP sheets is significant, and at the same time, the ultimate compressive bearing capacity of the column is greatly improved and the ductility of the column is significantly improved.

Pan Yi ,Cao Shuangyin etc. ${ }^{[2]}$ conducted axial compression tests on 16 square columns of concrete confined with CFRP sheets. He changed the load conditions and the number of CFRP layers to study the failure characteristics and mechanical properties of the columns. The test results show that the magnitude of the load applied to the column has a greater influence on the restraint effect of the CFRP cloth. As the applied load gradually increases, the peak point in the stress-strain curve gradually decreases; the restraint effect of the column increases with the increase in the number of CFRP cloth wrap layers.

Peng Yaping, Liu Zengxi, etc. ${ }^{[3]}$ conducted axial compressive tests on FRP-confined concrete square columns. The experiment is mainly divided into three groups to study the axial compressive performance of the square concrete column confined by strip FRP and the restraint mechanism of the section. The test results show that the confinement of the square concrete column section confined by FRP sheets is divided into strong confinement zone and weak confinement zone.

Deng Zongcai, Wang $\mathrm{Li}$ etc. ${ }^{[4]}$ conducted axial compression tests on square-section IHFRP-confined concrete columns and circular-section IHFRP-confined concrete columns. At the same time, they conducted axial compression tests on square plain concrete columns and circular plain concrete columns. Pressure test and compare them. The test results show that compared with plain concrete columns, the maximum compressive stress and maximum longitudinal linear strain of IHFRP-confined concrete columns are increased. 
Zhang Zhimei, Li Helin, etc. ${ }^{[5]}$ conducted a simulation analysis on a CFRP sheet-constrained rectangular concrete axial compression short column using finite element software to study the axial compression performance of the column. The research results show that the selected finite element model can simulate the entire deformation process well.

Wang Zuohu, Liu Jingbo, etc. ${ }^{[6]}$ conducted axial compression tests on FRP-confined rectangular cross-section concrete columns, mainly studying the influence of the size effect of the specimen on its mechanical properties, and at the same time the limit of existing FRP-confined circular concrete columns The expression of compressive strength calculation was optimized, and the theoretical calculation formula suitable for this test was derived. The research results show that the results calculated by the improved expression are in good agreement with the experimental data.

Peng Yaping, Zhang Ying etc. ${ }^{[7]}$ conducted axial compression tests on FRP-confined concrete short rectangular cross-section columns. He compared theoretical calculations and stresses obtained by axial compression tests. The stresses measured by axial compression tests were measured by piezoelectric sensors. Measured and established a numerical model between the stress measured by the sensor and the stress in the core area of the concrete short column. The research results show that the stresses obtained by the two methods are more consistent.

Shan Bo and Cai Jing ${ }^{[8]}$ conducted axial compression tests on CFRP-constrained square concrete columns. They studied the failure mode, maximum stress, stress-strain curve, and CFRP of the specimen by changing the chamfer size and other parameters of the section. Basic mechanical properties such as longitudinal linear strain distribution. The research results show that the axial compressive strength of the test piece increases with the increase of the chamfering radius of the cross section of the component. The damage of the component leads to the tearing of the fiber composite material on the periphery. The characteristic of the damage is that the CFRP is torn The positions of the cracks are all located within the range of the 
cylindrical corners of the section, and the restraint effect of CFRP decreases with the increase of the size of the specimen.

Tong $\operatorname{Lin}^{[9]}$ conducted axial compression tests on CFRP-constrained rectangular steel concrete short columns and ordinary rectangular steel-concrete short columns. He changed physical parameters such as the concrete strength grade of the specimen and the number of CFRP constrained layers to study the column-on-axis Destruction characteristics, ultimate bearing capacity, deformation characteristics and other axial compression performance under the condition of core compression. The research results show that the ultimate bearing capacity of CFRP-constrained rectangular steel concrete short columns increases with the increase of concrete strength; the restraining effect of CFRP-constrained rectangular steel-concrete short columns under pressure increases with the increase of the number of CFRP cloth layers.

Li Tao, Huang Jingming, etc. ${ }^{[10]}$ conducted axial compression tests on square plain concrete columns constrained by BFRP cloth. They changed the number of layers of BFRP cloth wound on plain concrete, the type of BFRP cloth material, and the way of BFRP cloth wrapping. The failure process and failure characteristics of the specimens are studied, and the changes in the ultimate bearing capacity and ductility of the square plain concrete columns with BFRP sheets are analyzed. The research results show that the increase in the number of BFRP cloth winding layers improves the axial compressive strength and ductility of the square plain concrete columns confined by BFRP cloth; the increase in compressive strength and ductility of the square plain concrete columns confined by BFRP cloth increases with BFRP As the number of cloth winding layers increases, it decreases.

Gao Peng, Wang Jingtang etc. ${ }^{[11]}$ conducted axial compression tests on rectangular steel concrete short columns confined by CFRP cloth. They changed the concrete strength grade to study the load-displacement curve of rectangular steel concrete short columns confined by CFRP cloth. The research results show that the cross-sectional constrained area of the rectangular steel concrete short column confined by CFRP cloth is divided into strong constrained area and weak constrained 
area; the relationship between the limit value and concrete strength is deduced, and the test data result is calculated by the revised formula. Coincide.

\section{Test overview}

\subsection{Test design}

In this experiment, 6 square steel tube confined concrete axial compression specimens and 6 BFRP square tube confined concrete axial compression specimens were produced. The strength grades of concrete are C30, C40, C50. The performance parameters of square steel pipes and square BFRP pipes are shown in Table 1-1. The serial number and basic parameters of the axially compressed short column specimens are shown in Table 1-2. Concrete mix design See Table 1-3.

Table 1-1 Performance parameters of restraint materials

\begin{tabular}{cccc}
\hline Material type & $\begin{array}{c}\text { Material } \\
\text { thickness }(\mathrm{mm})\end{array}$ & $\begin{array}{c}\text { Yield } \\
\text { Strength(MPa) }\end{array}$ & $\begin{array}{c}\text { Elastic } \\
\text { Modulus(GPa) }\end{array}$ \\
\hline Square steel pipe & 5 & 235 & 206 \\
Square BFRP pipe & 5 & 245 & 12 \\
\hline
\end{tabular}

Table 1-2 Numbers and basic parameters of test pieces of axial compression short column

\begin{tabular}{|c|c|c|c|c|c|}
\hline $\begin{array}{l}\text { Material } \\
\text { type }\end{array}$ & number & $\begin{array}{l}\text { Cross section } \\
\text { size }(\mathrm{mm})\end{array}$ & $\begin{array}{c}\text { Concrete } \\
\text { strength } \\
\text { grade }(\mathrm{MPa})\end{array}$ & $\mathrm{L}(\mathrm{mm})$ & $\mathrm{L} / \mathrm{B}$ \\
\hline \multirow{4}{*}{$\begin{array}{c}\text { Square steel } \\
\text { pipe }\end{array}$} & $\mathrm{GZ}_{0}$ & \multirow{4}{*}{$50 \times 50 \times 5$} & - & \multirow{4}{*}{150} & \multirow{4}{*}{3} \\
\hline & $\mathrm{GZ}_{1}$ & & $\mathrm{C} 30$ & & \\
\hline & $\mathrm{GZ}_{2}$ & & $\mathrm{C} 40$ & & \\
\hline & $\mathrm{GZ}_{3}$ & & C50 & & \\
\hline \multirow{2}{*}{$\begin{array}{c}\text { Square } \\
\text { BFRP pipe }\end{array}$} & $\mathrm{XZ}_{0}$ & \multirow{2}{*}{$50 \times 50 \times 5$} & - & \multirow{2}{*}{150} & \multirow{2}{*}{3} \\
\hline & $\mathrm{XZ}_{1}$ & & C30 & & \\
\hline
\end{tabular}




$\begin{array}{ll}\mathrm{XZ}_{2} & \mathrm{C} 40 \\ \mathrm{XZ}_{3} & \mathrm{C} 50\end{array}$

Note: $\mathrm{X}$ indicates that the constrained material is BFRP tube, $\mathrm{Z}$ indicates the axial compression stub, L indicates the calculated length of the axial compression stub, B indicates the cross-sectional width of the axial compression stub, and the angle marks $0,1,2$, and 3 represent the components respectively Number.

Table 1-3 Concrete mix design

\begin{tabular}{ccccccc}
\hline $\begin{array}{c}\text { Concrete } \\
\text { strength } \\
\text { grade }\end{array}$ & $\begin{array}{c}\text { Cement } \\
\text { type }\end{array}$ & $\begin{array}{c}\text { Water } \\
(\mathrm{kg})\end{array}$ & $\begin{array}{c}\text { Cement } \\
(\mathrm{kg})\end{array}$ & $\begin{array}{c}\text { Water } \\
\text { reducing } \\
\text { agent(kg) }\end{array}$ & $\begin{array}{c}\text { Machine- } \\
\text { made } \\
\text { sand(kg) }\end{array}$ & $\begin{array}{c}\text { Gravel } \\
(\mathrm{kg})\end{array}$ \\
\hline C30 & P.O 42.5 & 3.60 & 5.99 & 0.000 & 13.39 & 21.85 \\
C40 & P.O 42.5 & 3.60 & 7.37 & 0.015 & 11.27 & 22.87 \\
C50 & P.O 42.5 & 3.60 & 8.97 & 0.018 & 10.83 & 21.98 \\
\hline
\end{tabular}

\subsection{Specimen production}

When pouring, the square steel pipe and square BFRP pipe are placed on the electric vibrating table, and the top layer is poured and vibrated and compacted. After pouring is completed, the top of the axial compression column specimen is smoothed with cement slurry to make the plaster higher than the outer restraint material. After reaching the strength, it is smoothed with sandpaper to ensure that the restraint material and the core concrete can simultaneously bear axial pressure. Put the sorted axial compression test piece on a label and place it in a constant temperature room, and maintain it for 28 days under standard conditions. The specimens of square BFRP pipe-constrained concrete axial compression column and square steel pipe-constrained concrete axial compression column specimens are shown in Figure 1-1 and Figure 1-2, respectively. 


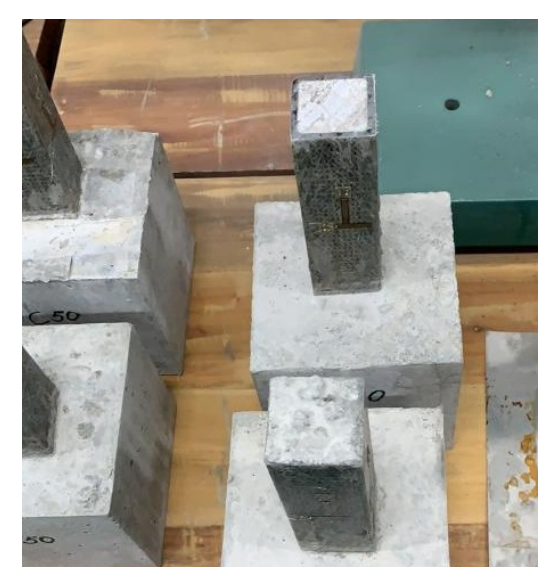

Figure 1-1 BFRP tube confined concrete axial compression test piece

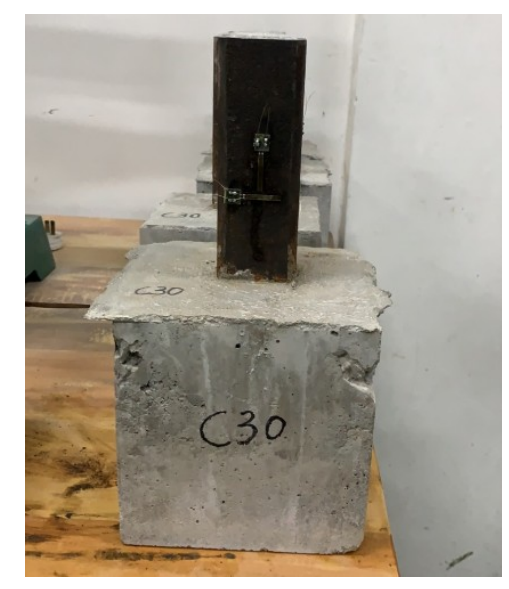

Figure 1-2 Axial compression test piece of steel tube confined concrete

\subsection{Axial compression test}

The axial compression test is carried out on a universal testing machine with a measuring range of $1000 \mathrm{KN}$. 8 strain gauges are pasted on each axial compression test piece, and 2 are pasted on each surface, that is, measuring points 1 to 4 measure longitudinal strain, and measuring points 5 to 8 measure circumferential strain. Each strain gauge is connected to a $3 \mathrm{~m}$ long wire, and the other end of the wire is connected to a strain collector. The strain collector uses a JM3813 static strain collector. The schematic diagram of the loading device for the axial compression test is shown in Figure 1-3, and the on-site loading diagram for the axial compression test is shown in Figure 1-4. 


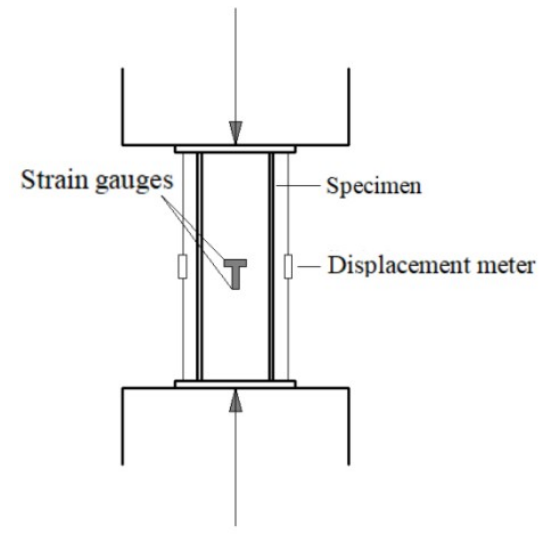

Figure 1-3 Loading device for axial compression test

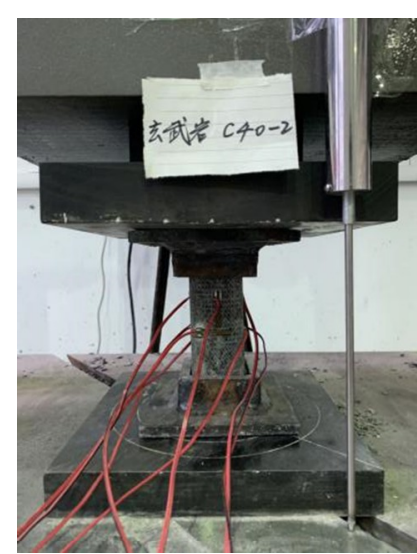

Figure 1-4 Field device diagram of axial compression test

\section{Test phenomenon and result analysis}

\subsection{Test phenomenon}

For concrete-filled steel tube members, as the axial load gradually increases, the axial displacement of the test piece gradually increases, the middle part of the test piece becomes thicker, and finally the middle part of the test piece has a larger bulge deformation, and the outer steel pipe cracks in the middle part, and the concrete is compressed. The specimen is pressed into a stubby shape, and the press automatically stops applying load. The failure characteristics of square steel tube confined concrete columns are shown in Figure 2-1.

For BFRP pipe-constrained concrete members, as the axial load gradually increases, the middle part of the specimen is slightly bulging, and accompanied by a crackling sound, the specimen begins to crack axially from the middle near the four corners, and the cracks gradually spread to both ends, And the cracks are getting bigger and bigger. When the applied load reaches the maximum, the axial cracks on the BFRP square tube around the specimen develop slowly, and the load gradually decreases. Because the two ends of the test piece are in close contact with the press and the friction is relatively large, the two ends of the BFRP tube of the test piece are crushed. Finally, the cracks on the BFRP constrained material penetrated the entire height, losing the hoop confinement ability of the core concrete, and the press 
automatically stopped applying load. The failure characteristics of the concrete column confined by the square BFRP pipe are shown in Figure 2-2.

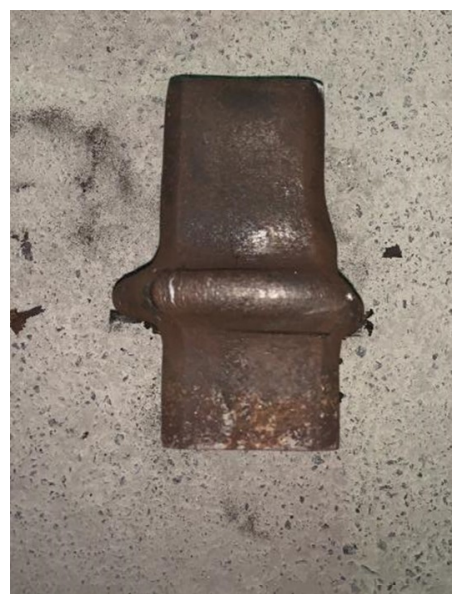

Figure 2-1 The failure characteristics of a square steel tube confined concrete column

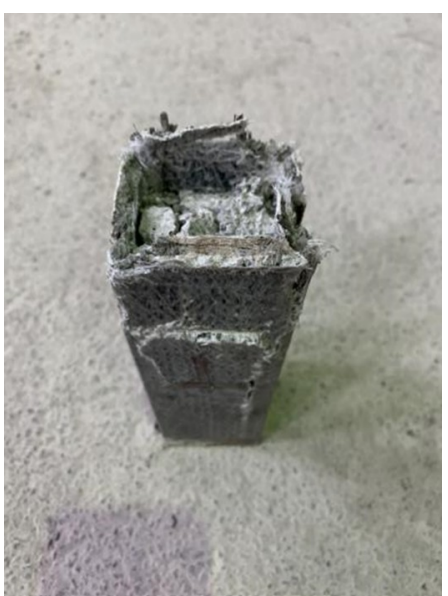

Figure 2-2 Failure characteristics of concrete columns confined by BFRP pipes

\subsection{Analysis of test results}

Axial compression test is carried out on the concrete column confined by the square steel tube and the concrete column confined by the BFRP pipe, the load value and displacement value are recorded, and the load-displacement curve is drawn. The load displacement of different restraint materials and different concrete strength grade specimens is shown in the figure below. The "Steel" curve in the graph represents the results of the axial compression test of the steel tube-constrained concrete column. The "FRP" curve in the graph represents the test results of a BFRP square tube confined concrete axially compressed short column. The abscissa in the graph represents displacement, which is represented by " $\Delta$ " (unit: $\mathrm{mm}$ ). The ordinate in the graph represents the load, which is represented by "P" (unit: KN). The curves of different restraint materials and different concrete strength grade specimens are shown in Figure 2-3. 


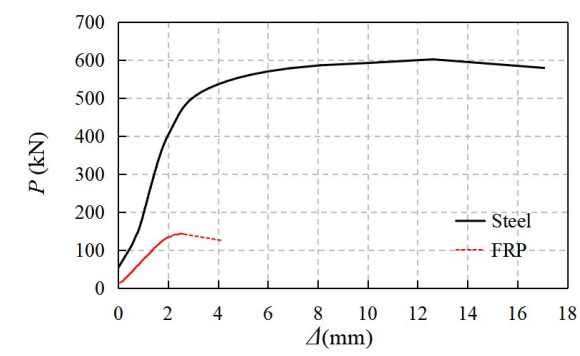

(a) Load-displacement curve of C30 column

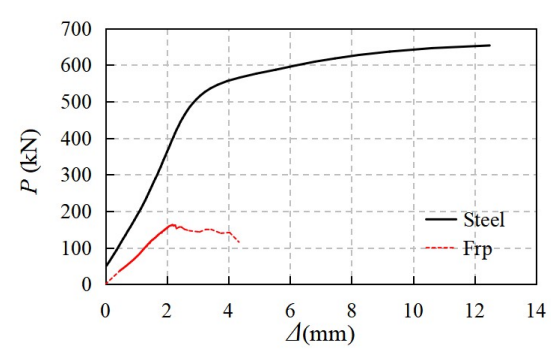

(b) Load-displacement curve of C40

column

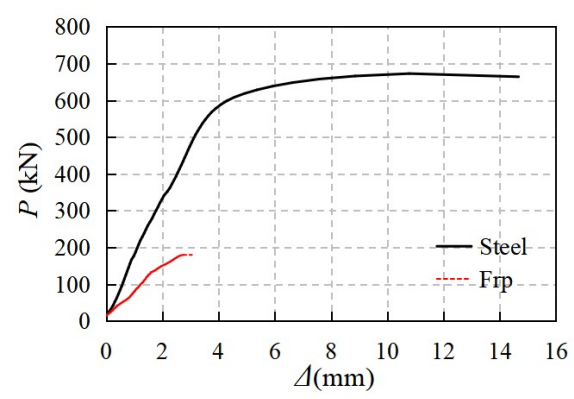

(c) Load-displacement curve of C50 column

Figure 2-3 Load-displacement curves of two restraint material columns

In Figure 2-3(a), the ultimate load of the square steel tube concrete column is $602.03 \mathrm{KN}$ and the ultimate displacement is $12.62 \mathrm{~mm}$; the ultimate load of the BFRP pipe-constrained concrete column is $141.71 \mathrm{KN}$, and the ultimate displacement is $2.63 \mathrm{~mm}$. In Figure 2-3(b), the ultimate load of the square steel tube concrete column is $653.27 \mathrm{KN}$ and the ultimate displacement is $12.49 \mathrm{~mm}$; the ultimate load of the BFRP tube-constrained concrete column is $156.74 \mathrm{KN}$, and the ultimate displacement is $2.40 \mathrm{~mm}$. In Figure 2-3(c), the ultimate load of the square steel tube confined concrete column is $672.64 \mathrm{KN}$ and the ultimate displacement is $10.78 \mathrm{~mm}$; the ultimate load of the BFRP tube confined concrete column is $181.22 \mathrm{KN}$, and the ultimate displacement is $3.05 \mathrm{~mm}$. 


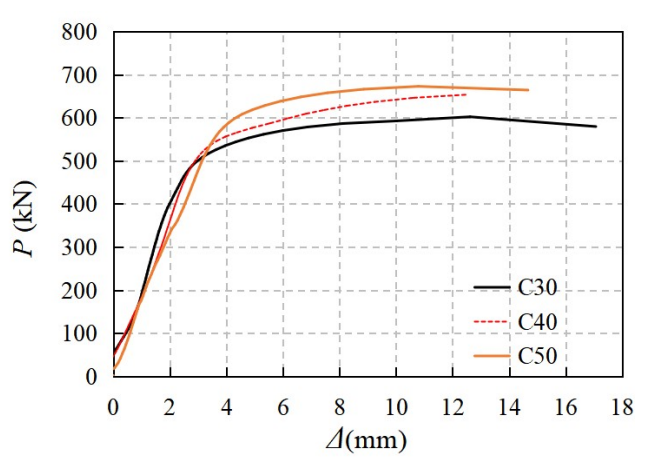

(a) Load-displacement curve of steel pipe column

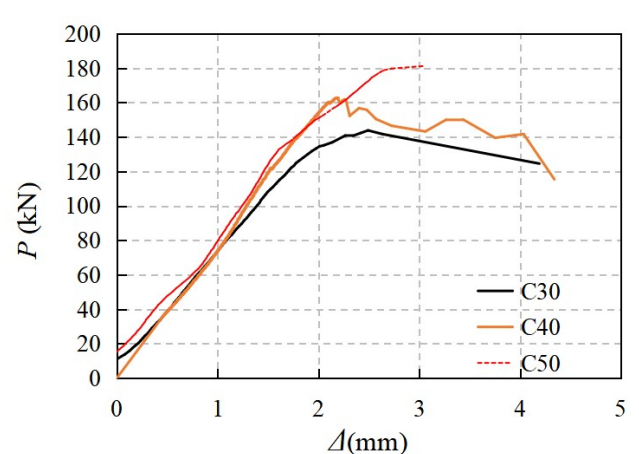

(b) Load-displacement curve of BFRP column

图 2-4 C30、C40、C50 钢管柱和 BFRP 柱的 $P-\Delta$ 曲线

It can be seen from Figure 2-4(a) that the axial compressive ultimate bearing capacity of concrete columns confined by steel tubes increases with the increase of the concrete strength grade; the ultimate displacement decreases with the increase of the concrete strength grade. It can be seen from Figure 2-4(b) that the ultimate bearing capacity of the BFRP square tube confined concrete bearing column under axial compression gradually increases with the increase of the core concrete strength grade; the ultimate displacement increases with the increase of the concrete strength grade. Gradually increase.

The measured values of the axial compressive ultimate load of the square steel tube confined concrete column and the square BFRP pipe confined concrete column are shown in Table 2-1.

Table 2-1 Test results of ultimate load of axial compression specimen

\begin{tabular}{cccc}
\hline $\begin{array}{c}\text { Types of } \\
\text { restraint } \\
\text { materials }\end{array}$ & $\begin{array}{c}\text { Strength grade of } \\
\text { concrete(MPa) }\end{array}$ & $\begin{array}{c}\text { Measured ultimate } \\
\text { load(KN) }\end{array}$ & $\begin{array}{c}\text { Increase in ultimate } \\
\text { bearing capacity(\%) }\end{array}$ \\
\hline \multirow{2}{*}{ Steel Pipe } & $\mathrm{C} 30$ & 602.03 & 0 \\
& $\mathrm{C} 40$ & 653.27 & 8.51 \\
\hline BFRP & $\mathrm{C} 30$ & 672.64 & 11.73 \\
\hline
\end{tabular}




$\begin{array}{llll}\text { Pipe } & \text { C40 } & 156.74 & 10.61 \\ & \text { C50 } & 181.22 & 27.88\end{array}$

For square steel tube confined concrete columns, changing the strength grade of concrete, the increase in axial compressive ultimate bearing capacity of C40 compared with $\mathrm{C} 30$ is $8.51 \%$, and the increase in ultimate bearing capacity of C50 compared with $\mathrm{C} 30$ is $11.73 \%$; for square BFRP pipes By constraining the concrete column and changing the strength level of concrete, the ultimate bearing capacity of $\mathrm{C} 40$ and $\mathrm{C} 30$ is increased by $10.61 \%$ compared with $\mathrm{C} 30$, and the ultimate bearing capacity of C50 is increased by $27.88 \%$ compared with C30.

Based on the above analysis, it can be seen that as the concrete strength level of the square steel tube confined concrete column increases, the ultimate bearing capacity of the axial compression increases less, while the square BFRP pipe confined concrete column increases more.

Table 2-2 Test results of ultimate displacement of axial compression test piece

\begin{tabular}{cccc}
\hline $\begin{array}{c}\text { Types of } \\
\text { restraint } \\
\text { materials }\end{array}$ & $\begin{array}{c}\text { Strength grade of } \\
\text { concrete(MPa) }\end{array}$ & $\begin{array}{c}\text { Maximum } \\
\text { displacement } \\
\text { measured(mm) }\end{array}$ & $\begin{array}{c}\text { Maximum displacement } \\
\text { increase(\%) }\end{array}$ \\
\hline \multirow{2}{*}{ Steel Pipe } & C30 40 & 12.62 & 0 \\
& $\mathrm{C} 50$ & 12.49 & -1.03 \\
\hline \multirow{2}{*}{ BFRP } & $\mathrm{C} 30$ & 10.78 & -14.58 \\
& $\mathrm{C} 40$ & 2.63 & -8.75 \\
& $\mathrm{C} 50$ & 2.40 & 15.97 \\
\hline
\end{tabular}

For square steel tube confined concrete columns, the maximum displacement of $\mathrm{C} 40$ is $-1.03 \%$ compared with $\mathrm{C} 30$; the maximum displacement of $\mathrm{C} 50$ is $-14.58 \%$ 
compared with $\mathrm{C} 30$. For concrete columns confined by square BFRP pipes, the maximum displacement increase of $\mathrm{C} 40$ compared with $\mathrm{C} 30$ is $-8.75 \%$; compared with $\mathrm{C} 30$, the maximum displacement increase is $15.97 \%$.

Based on the above analysis, it is known that the maximum displacement of the square steel tube-confined concrete column gradually decreases with the increase of the concrete strength level, while the square BFRP tube-confined concrete column shows the characteristics of first decreasing and then increasing.

\section{Simulation analysis}

\subsection{Constitutive relation model}

\subsubsection{Selection of Concrete Constitutive Model}

Concrete can be regarded as an isotropic material when using software simulation analysis. The constitutive model of concrete in this paper adopts the model in the Chinese National Standard "Specification for Design of Concrete Structures" (GB50010-2010) ${ }^{[12]}$, and its expression is shown in the following formula:

$$
\begin{aligned}
& \sigma_{c}=f_{c}\left[1-\left(1-\frac{\varepsilon}{\varepsilon_{0}}\right)^{n}\right] \quad \varepsilon \leq \varepsilon_{0} \\
& \left\{\begin{array}{l}
\sigma_{c}=f_{c} \\
\varepsilon_{c u}=\frac{33}{10000}-\left(f_{c u, k}-50\right) \times 10^{-5} \\
\varepsilon_{0}=\frac{1}{500}+\frac{1}{2}\left(f_{c u, k}-50\right) \times 10^{-5} \quad \varepsilon_{0}<\varepsilon \leq \varepsilon_{c} \\
n=\frac{120-\left(f_{c u, k}-50\right)}{60}
\end{array}\right.
\end{aligned}
$$

Where $\sigma$ is the axial stress of the concrete; $\varepsilon$ is the axial strain of concrete; $n$ is the adjustment factor, take $n \leq 2 ; \varepsilon_{0}$ represents the strain value of concrete under maximum stress,take $\varepsilon_{0}=0.002 ; \varepsilon_{c u}$ is the maximum compressive strain of 
concrete, take $\varepsilon_{c u}=0.0033 ; f_{c}$ is the design value of the axial compressive strength of the concrete test block; $\mathrm{A}$ is the standard value of the axial compressive strength of the concrete cube test block; $f_{c u, k}$ is the standard value of the axial compressive strength of the concrete cube test block.

\subsubsection{Selection of constitutive relationship of square BFRP tube}

As a composite material, BFRP pipe exhibits linear elasticity when it bears axial tension. For a short column under axial compression, the BFRP tube mainly provides lateral constraints, ignoring the constraints provided by the axial direction, the transverse stress-strain relationship is shown in the following equation:

$$
\sigma_{f}=E_{f} \times \varepsilon_{f}
$$

Where $\sigma_{f}$ is the stress of the BFRP tube; $E_{f}$ is the elastic modulus of BFRP tube; $\varepsilon_{f}$ is the linear strain of the BFRP tube.

\subsection{ABAQUS build model analysis}

\subsubsection{Establishment of ABAQUS model}




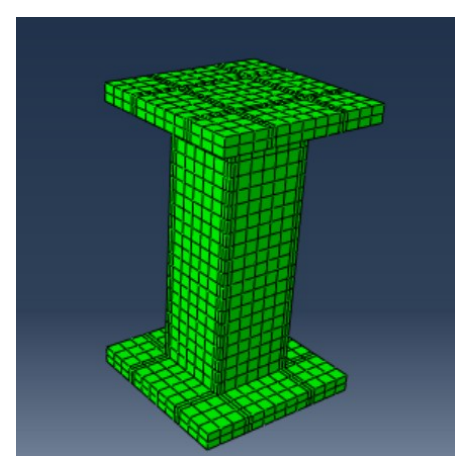

Figure 3-1 Elevation view of BFRP pipe confined concrete column model

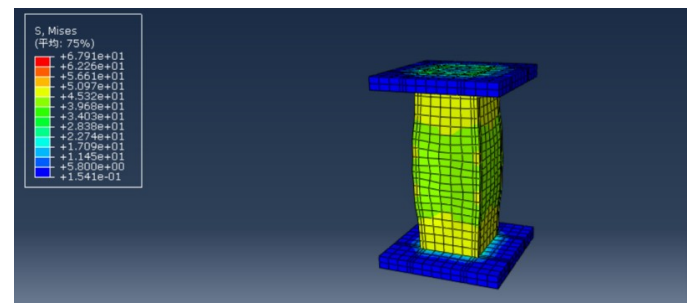

(a) C30 BFRP pipe confined concrete column stress cloud diagram

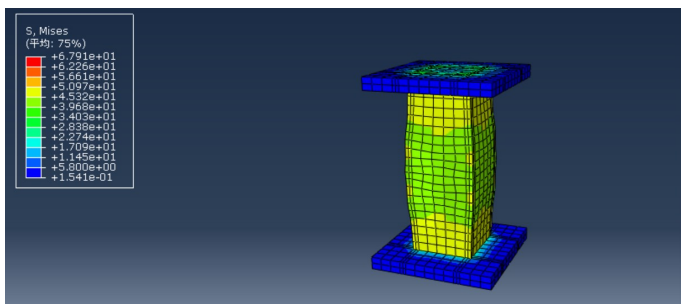

(b) C40 BFRP pipe confined concrete column stress cloud diagram

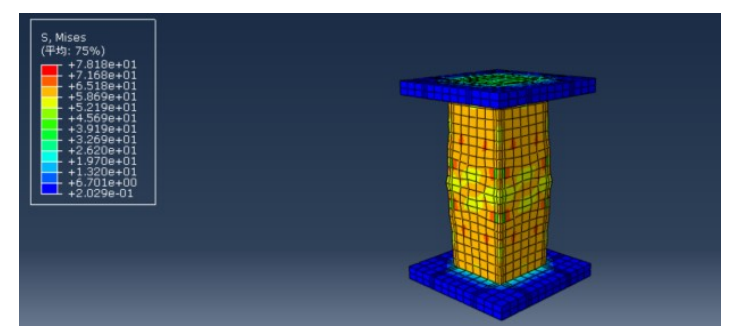

(c) C50 BFRP pipe confined concrete column stress cloud diagram

Figure 3-2 Stress cloud diagram of concrete members confined by BFRP pipe

The comparison between the ABAQUS analysis result and the test result of the load-displacement curve of the concrete column confined by the square BFRP tube is shown in Figure 3-3.

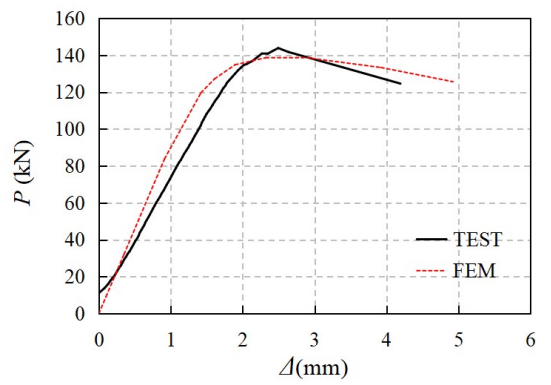

(a) Load displacement diagram of

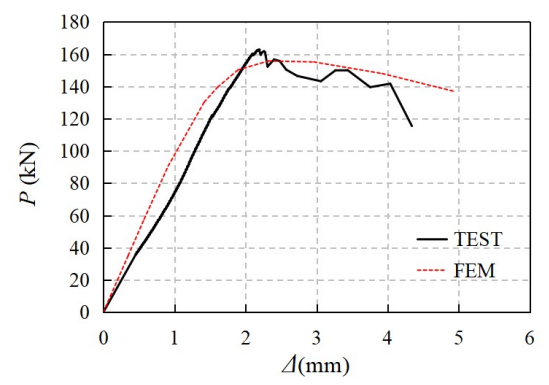

(b) Load displacement diagram of 
concrete column confined by C30 BFRP
pipe

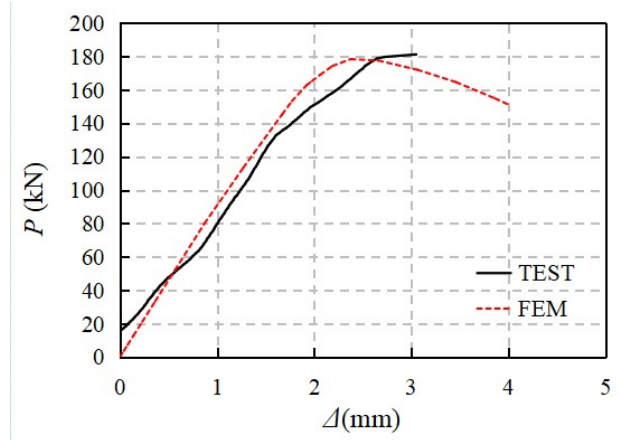

(c) Load displacement diagram of concrete column confined by C50 BFRP pipe

Figure 3-3 Comparison of ABAQUS analysis results and test results

From the analysis results in the above figure, the simulation results are in good agreement with the experimental data results, indicating that the ABAQUS model used in this paper can basically reflect the axial compression performance of the BFRP tube-confined concrete short column.

\section{Conclusions}

As a new type of composite material, BFRP pipes have been studied relatively little, and are currently used in engineering fields less. In order to study its basic mechanical properties, this paper selects Q235 steel square pipes and BFRP square pipes for comparative research.

(1) The maximum compressive bearing capacity of concrete columns confined by square BFRP tubes is less than that of concrete columns confined by square steel tubes. With the improvement of the concrete strength level of the square steel tube confined concrete column, the increase in compressive bearing capacity is smaller, while the improvement of the square BFRP pipe confined concrete column is larger;

(2) The failure characteristics of square BFRP pipe-confined concrete columns are different from those of square steel-tube-confined concrete columns. When the concrete-filled steel tube is damaged under compression, the middle bulge damages, while the BFRP tube-constrained concrete column has cracks running through the 
entire column height and damage occurs at the column corners. When the concrete-filled steel tube beam fails in bending, the cracks will crack from the bottom upwards in the middle of the span, causing the members to lose the bearing capacity. From the point of view of the failure characteristics of BFRP pipe confined concrete columns, this is caused by the insufficient provision of BFRP pipe hoop restraint.

(3) According to the simulation results carried out by the finite element software, it is more consistent with the experimental data results and the error is small, indicating that the finite element model established by the selected constitutive model is reasonable.

\section{References}

[1]Dong Lei. Experimental research and theoretical analysis on the axial compression performance of FRP-confined concrete[D]. Xi'an University of Architecture and Technology, 2007.

[2]Pan Yi,Cao Shuangyin,Jing Denghu,Chen Debao.Experimental research and analysis on the stress-strain relationship of concrete square columns confined with carbon fiber sheets under load[J].China Civil Engineering Journal,2009,42(01):23-29.

[3]Peng Yaping,Liu Zengxi,Ma Ming.Analysis of Axial Compression Bearing Capacity of FRP-Confined Concrete Square Columns[J].Journal of Wuhan University of Technology,2010,32(03):24-28.

[4]Deng Zongcai,Wang Li.Experimental Study on the Axial Compressive Characteristics of Concrete Columns Confined by Hybrid Fiber Sheets[J].Journal of Beijing University of Technology,2012,38(02):161-166.

[5]Zhang Zhimei,Li Helin,Zhang Yanxu.Nonlinear finite element analysis of the axial compression performance of short rectangular concrete columns confined with CFRP sheets[J].Journal of Shanghai University (Natural Science Edition),2013,19(02):203-207. 
[6]Wang Zuohu,Liu Jingbo,Du Xiuli.Research on the stress-strain relationship of FRP-reinforced rectangular cross-section concrete columns under uniaxial axial compression load considering the size effect[J].FRP/Composite Materials,2014(06):35-39.

[7]Peng Yaping,Zhang Ying,Huang Shifeng. Sensor measurement of stress in the core area of FRP-confined concrete axially compressed short columns[J].Chinese Journal of Composites,2015,32(02):549-556.

[8]Shan Bo,Cai Jing,Xiao Yan,Giorgio Monti.Experimental study on the axial compression of large-size CFRP-confined concrete square columns[J].Journal of Hunan University(Natural Science Edition),2016,43(03):75-82.

[9]Tong Lin. Study on the axial compression performance of CFRP-constrained steel concrete rectangular short columns under different concrete strength grades[D]. Hefei University of Technology, 2017.

[10]Li Tao,Huang Jingzhu,Zhou An,Zhan Binggen,Zhu Dayong,Dai Liangjun,Chen Gang.Study on the axial compression performance of plain concrete square columns reinforced with basalt fiber composite sheet[J].Industrial Construction,2018,48(02):182-187.

[11]Gao Peng,Wang Jingtang,Tong Lin,Hong Li.Determination of the strength and weakness constraint limits of different strength concrete columns reinforced with composite material[J].Industrial Construction,2019,49(09):118-123.

[12]National Standard of the People's Republic of China. Design Code for Concrete Structures (GB50010-2010). Beijing: China Building Industry Press, 2010. 